\title{
COLOPOSCOPY AND OFFICE HYSTEROSCOPY FOR CERVICAL ASSESSMENT FOR EVALUATION OF SUSPICIOUS CERVIX
}

\author{
By
}
Mohammed Mamdouh Sayed*, Faisal Ali Mustafa *, Hussein A.H. Gadallah** and Abd El-Halim Mohammed Abd El-Halim*

Department of Obstetrics and Gynecology*, Department of Pathology**, Faculty of Medicine, Al-Azhar University (Assiut)

E-mail: $\underline{\text { m_mamdouh91@yahoo.com }}$

\begin{abstract}
Background: Cervical cancer is the second most common cancer among women in developing countries. Cervical cancer is a deadly disease once it reaches the invasive stages but out of all the female genital tract cancers. It is the only preventable cancer if detected in its early stages, and the disease is almost $100 \%$ curable with accurate screening and early detection.

Objective: To evaluate efficacy of both office cervicoscopy and colposcopy directed biopsy in evaluation of clinically suspicious cervix.

Patients and methods: Prospective cohort study on 200 patients with clinically suspicious cervix attending the outpatient Department of Obstetrics and Gynecology, at the Hospital of Al-Azher Assiut University. Results: Colposcopy had a sensitivity of $60 \%$ and a specificity of $91.1 \%$. Office cervicoscopy showed a sensitivity of $75 \%$ and a specificity of $89.3 \%$.

Conclusions: Office cervicoscopy is more sensitive than stationary colposcopy for detection of cervical lesions in cases with suspicious cervix as an example of high risk group for cervical cancer. Its small caliber allows easy, simple and fast diagnostic out-patient evaluation of the cervix.
\end{abstract}

Keywords: Screening of suspicious cervix, Coloposcopy and office hysteroscopy, punch biopsy, cervical histopathology.

\section{INTRODUCTION}

Cervical cancer is one of the leading causes of cancer-related deaths in developing countries worldwide, with incidence rates varying considerably from 528000 new cases and more than with an about the reasons for this high incidence due to lack of valuable screening curriculums and poor organized resources (Ferlay et al., 2017).

Traditional screening for cervical cancer is done with papanicolaou smear test, colposcopic examination and colposcopic directed biopsy for histopathology. Pap smears have formed the basis of cervical cancer screening and detection programs for many years. National cytology-based screening programs have contributed substantially to the marked decline in deaths from cervical cancer in these countries (ACOG, 2016).

Cervical lesions such as ectropion, nabothian cysts, and small cervical polyps are quite benign and may need not generate concern for patient or clinician, 
In some patients, the cervix may be difficult to visualize. Several useful clinical suggestions for the optimal examinations of the cervix are presented (Casey et al., 2011).

Colposcopy is currently used for management of abnormal pap smears, and is the second step of diagnostic approach. The assessment of women with abnormal cytology and selection of those who require further therapy or follow up depends on the colposcopic assessment of the TZ (Quaas et al., 2011).

Colposcopy practice includes the complete colposcopy visit from visual assessment of the cervix to biopsy sampling if indicated. Colposcopy should be viewed as a risk assessment tool that directs subsequent management with biopsies, treatment, or observation. When a lesion(s) is/are present, colposcopydirected biopsies of 2 to 4 sites are taken to establish a histopathologic diagnosis of the most severe disease present. For lowrisk women with a normal colposcopic impression, deferring biopsies may be acceptable (Wentzensen et al., 2017).

The endocervicoscopy report is based on colposcopic theoretic principles and visible lesions are classified under specific categories on the basis of their severity, according to the international federation of cervical pathology and colposcopy (Walzer et al., 2013).

Today, many hysteroscopic procedures can be performed in the office or outpatient setting. This is due to the feasibility of operative hysteroscopy using saline as distending medium. There is good evidence to suggest that hysteroscopy in an ambulatory setting is preferable for the patient, and that it avoids complications, allows a quicker recovery time and lowers cost (Centini et al., 2016).

\section{PATIENTS AND METHODS}

This was a prospective study included 200 Women. The study participants were recruited from Obstetrics and Gynecology outpatient clinic at the Department of Obstetrics and Gynecology of Al-Azhar University Hospital (Assiut)

The local ethics committee of AlAzhar University Hospital (Assiut) Egypt had approved this study from November 2019 till April 2020.

\section{Inclusion Criteria:}

Women in age group of 20-60 years associated with:

1. Persistent vaginal discharge.

2. Post coital bleeding.

3. Cervical hypertrophy.

4. Cervical erosion/ ulceration/ growth/ oozing surface.

5. Contact bleeding.

6. Cervix flushed with petechial spot.

7. Unexplained occasional foul smelling discharge per vagina.

\section{Exclusion criteria:}

1. Pregnant or postpartum or post abortive patients.

2. Patient having any history of treatment for either cervical dysplasia or vulval warts.

3. Patient who had underwent to recent endometrial curettage, hysterosalpingography, cervical biopsy or hysterectomy. 
4. Immunocompromised patients (HIV patient on corticosteroids).

Patients were divided into 2 equal groups: Group A for office hysteroscope, and group B for colposcopy. The details and purpose of the study were explained to participants attending the outpatient clinic and oral consents were taken. Information on socio-demographic and reproductive variables was collected during an interview using a patient sheet.

\section{Colposcopic examination included 5} steps:

1. $0.9 \%$ saline technique to assess the cervical lesion and vasculature of the cervix.

2. 5\% acetic acid technique to determine acetowhite-positive area.

3. Schiller's iodine technique to visualize high glycogen containing cells.

4. Endo-cervical canal assessment using (Bossman forceps or endocervical speculum)

5. Biopsy using the punch biopsy forceps. Biopsy was obtained from every abnormal colposcopic examination. Using the same instruments used for traditional hysteroscopy, an office hysteroscopy was with telescope $2.6 \mathrm{~mm}$, outer sheath $3.6 \mathrm{~mm}$, a digital end camera and high-resolution monitor, and included the following steps: a. $0.9 \%$ saline technique to assess the cervical lesion and vasculature of the cervix.

b. $5 \%$ acetic acid technique to determine aceto white-positive area.

c. Schiller's iodine technique to visualize high glycogen containing cells.

d. Endocervical canal assessment .

e. Biopsy using the punch biopsy forceps. Biopsy was obtained from every abnormal hysteroscopic examination for histopathological examination.

Women with positive findings after histopathological examination were advised to continue follow-up care after proper management, and they were scheduled for follow up examination.

\section{Statistical analysis:}

Statistical analysis was performed using Statistical package for social science (SPSS) version 25.

The following tests were used: Descriptive analysis of the results in the form of percentage distribution for qualitative data (minimum, maximum, mean and standard deviation) calculation for quantitative data.

- P value was considered significant when $\mathrm{P} \leq 0.05$.

\section{RESULTS}

There were no statistically significant differences between the two groups regarding the use of contraceptive methods, types of contraceptive methods, family history of cervical cancer or perior cervical lesions (Table 1). 
MOHAMMED MAMDOUH SAYED et al.,

Table (1): Risk factor for pre-invasive cervical lesions of studied women

\begin{tabular}{|c|c|c|c|c|c|}
\hline \multirow[t]{2}{*}{ Parameters } & \multicolumn{2}{|c|}{$\begin{array}{c}\text { Group A } \\
\text { (Cervicoscope) } \\
(\mathrm{N}=56) \\
\end{array}$} & \multicolumn{2}{|c|}{$\begin{array}{c}\text { Group B } \\
(\text { Colposcope }) \\
(\mathrm{N}=56) \\
\end{array}$} & \multirow[t]{2}{*}{$\begin{array}{c}\mathrm{P} \\
\text { Value }\end{array}$} \\
\hline & No & $\%$ & No & $\%$ & \\
\hline \multicolumn{6}{|c|}{ Use Of Contraceptive Methods } \\
\hline Yes & 37 & 66.1 & 40 & 71.4 & \multirow{2}{*}{0.541} \\
\hline No & 19 & 33.9 & 16 & 28.6 & \\
\hline \multicolumn{6}{|c|}{ Types Of Contraceptive Methods } \\
\hline Cocs & 23 & 62.2 & 24 & 60.0 & .0 .846 \\
\hline Pops & 0 & 0 & 4 & 10.0 & 0.116 \\
\hline Iud & 20 & 54.1 & 19 & 46.5 & 0.565 \\
\hline Implanone & 4 & 10.8 & 2 & 5 & 0.419 \\
\hline Monthly Injectable & 1 & 2.7 & 1 & 2.5 & 1.000 \\
\hline $\begin{array}{l}\text { Depoprovera150mg } \\
\text { Every } 3 \text { Months }\end{array}$ & 6 & 16.2 & 1 & 2.5 & 0.051 \\
\hline \multicolumn{6}{|c|}{ Family History Of Cevical Cancer } \\
\hline Yes & 2 & 3.6 & 3 & 5.4 & \multirow{2}{*}{0.647} \\
\hline No & 54 & 96.4 & 53 & 94.6 & \\
\hline \multicolumn{6}{|l|}{ Prior Cervical Procedure } \\
\hline None & 55 & 98.2 & 54 & 96.4 & 0.558 \\
\hline Conization & 1 & 1.8 & 0 & 0 & 1.000 \\
\hline Cauterization & 0 & 0 & 2 & 3.6 & 0.495 \\
\hline
\end{tabular}

The studied women of group (A) reported more spontaneous vaginal which was statistically significant bleeding than women of group (B)

(Table 2).

Table (2): Main symptoms of the studied women

\begin{tabular}{|l|c|c|c|c|c|}
\hline \multirow{2}{*}{ Groups } & \multicolumn{2}{|c|}{$\begin{array}{c}\text { Group A } \\
\text { Main Complaints }\end{array}$} & \multicolumn{2}{c|}{$\begin{array}{c}\text { Group B } \\
\text { (Colposcope) } \\
\text { (N=56) }\end{array}$} & \multirow{2}{*}{ P-Value } \\
\cline { 2 - 5 } & $\mathbf{N O}$ & $\mathbf{\%}$ & $\mathbf{N O}$ & $\mathbf{\%}$ & \\
\hline CONTACT BLEEDING & 14 & 25.0 & 19 & 33.9 & 0.300 \\
\hline $\begin{array}{l}\text { SPONTANEOUS VAGINAL } \\
\text { BLEEDING }\end{array}$ & 26 & 46.4 & 13 & 23.2 & 0.010 \\
\hline PELVIC PAIN & 21 & 37.5 & 18 & 32.1 & 0.552 \\
\hline BACHACHE & 32 & 57.1 & 35 & 62.5 & 0.563 \\
\hline DYSPAREUNIA & 30 & 53.6 & 34 & 60.7 & 0.445 \\
\hline VAGINAL DISCHARGE & 39 & 69.6 & 37 & 66.1 & 0.686 \\
\hline
\end{tabular}

There were no statistically significant difference between the two groups regarding cervical ectopy, cervical ectropion, cervical mass, nabothian cyst, cervical ulcer, hypertrophied cervic, cervical polyp, inflammatory spots and cervical warts (Table 3). 
COLOPOSCOPY AND OFFICE HYSTEROSCOPY FOR CERVICAL...

Table (3): Naked eye examination of the cervix of the studied women

\begin{tabular}{|c|c|c|c|c|c|}
\hline \multirow{2}{*}{$\begin{array}{c}\text { Naked eye } \\
\text { Examination of the cervix }\end{array}$} & \multicolumn{2}{|c|}{$\begin{array}{c}\text { Group A } \\
\text { (Cervicoscope) } \\
\text { (N=56) }\end{array}$} & \multicolumn{2}{c|}{$\begin{array}{c}\text { Group B } \\
\text { (Colposcope) } \\
\text { (N=56) }\end{array}$} & \multirow{2}{*}{ P-Value } \\
\cline { 2 - 5 } & $\mathbf{N O}$ & $\mathbf{\%}$ & $\mathbf{N O}$ & $\mathbf{\%}$ & \\
\hline Cervical ectopy & 43 & 76.8 & 43 & 76.8 & 1.000 \\
\hline Cervical ectropion & 2 & 3.6 & 1 & 1.8 & 0.558 \\
\hline Cervical mass & 2 & 3.6 & 3 & 5.4 & 0.647 \\
\hline Napothian follicle & 9 & 16.1 & 10 & 17.9 & 0.801 \\
\hline Cervical ulcer & 1 & 1.8 & 1 & 1.8 & 1.000 \\
\hline Hypertrophic cervix & 8 & 14.3 & 4 & 7.1 & 0.222 \\
\hline Cervical polyps & 8 & 14.3 & 7 & 12.5 & 0.781 \\
\hline White spots & 1 & 1.8 & 1 & 1.8 & 1.000 \\
\hline Inflammatory spots & 1 & 1.8 & 0 & 0.0 & 1.000 \\
\hline Cervical warts & 1 & 1.8 & 1 & 1.8 & 1.000 \\
\hline
\end{tabular}

Women of group (B) reported more painless than group (A) which was statistically significant. Women of group (A) reported more tolerable pain than group (B) which were statistically significant. There were no statistically significant difference between the two groups regarding examination, type of abnormalities, Schiller's iodine, accessibility of endocervical and endometrial cavity (Table 4).

Table (4): Office cervicoscopic and colposcopic findings in both groups

\begin{tabular}{|c|c|c|c|c|c|}
\hline \multirow{2}{*}{ Parameters } & \multicolumn{2}{|c|}{$\begin{array}{c}\text { Group A } \\
\text { (Cervicoscope) } \\
(\mathrm{N}=56)\end{array}$} & \multicolumn{2}{|c|}{$\begin{array}{c}\text { Group B } \\
\text { (Colposcope) } \\
(\mathrm{N}=56)\end{array}$} & \multirow[t]{2}{*}{ P-Value } \\
\hline & NO & $\%$ & NO & $\%$ & \\
\hline \multicolumn{6}{|l|}{ Examination } \\
\hline Suspicios abnormalities & 8 & 14.3 & 6 & 10.7 & 0.568 \\
\hline Inflamatory & 48 & 85.7 & 46 & 82.2 & 0.607 \\
\hline Unsatisfactory & 0 & 0 & 4 & 7.1 & 0.118 \\
\hline \multicolumn{6}{|l|}{ Types ofsuspiciusabnormalitiesd } \\
\hline Abnormal vasculature & 3 & 37.5 & 2 & 33.3 & 1.000 \\
\hline Punctuation & 1 & 12.5 & 1 & 16.7 & 1.000 \\
\hline Mosaic appearance & 1 & 12.5 & 1 & 16.7 & 1.000 \\
\hline Acetoehite areas & 3 & 37.5 & 2 & 33.3 & 1.000 \\
\hline \multicolumn{5}{|l|}{ Schiller's test } & \multirow{3}{*}{0.067} \\
\hline Positive & 9 & 16.1 & 3 & 5.4 & \\
\hline Negative & 47 & 83.9 & 53 & 94.6 & \\
\hline \multicolumn{5}{|l|}{$\begin{array}{l}\text { Accessibility of endocervical and } \\
\text { evdometrial cavity }\end{array}$} & \multirow{3}{*}{--} \\
\hline Accessible & 49 & 87.5 & -- & -- & \\
\hline $\begin{array}{l}\text { Not accessible due to internals } \\
\text { stenosis }\end{array}$ & 7 & 12.5 & -- & -- & \\
\hline \multicolumn{6}{|l|}{ Pain during procedure } \\
\hline Paifull & 8 & 14.3 & 7 & 12.5 & 0.481 \\
\hline Painless & 26 & 46.4 & 43 & 76.7 & 0.001 \\
\hline Tolerable & 22 & 39.3 & 6 & 10.7 & $<0.0001$ \\
\hline
\end{tabular}


There was no statistically significant difference between the two groups as regarding histopathology. Chronic nonspecific cervicitis was the most frequent diagnosis in both groups; $69.6 \%$ in group A and $71.4 \%$ in group B (Table 5).

Table (5): Histopathology of biopsy specimen of the studied Women

\begin{tabular}{|c|c|c|c|c|c|}
\hline \multirow{2}{*}{ Diagnosis } & \multicolumn{2}{|c|}{$\begin{array}{c}\text { Group A } \\
\text { (Cervicoscope) } \\
(\mathbf{N}=56)\end{array}$} & \multicolumn{2}{|c|}{$\begin{array}{c}\text { Group B } \\
(\text { Colposcope }) \\
(\mathbf{N}=56)\end{array}$} & \multirow[t]{2}{*}{ P-Value } \\
\hline & NO. & $\%$ & NO. & $\%$ & \\
\hline $\begin{array}{l}\text { Chronic heavy lymhpocytic } \\
\text { cervicitis }\end{array}$ & 4 & 7.1 & 0 & 0.0 & 0.118 \\
\hline Chronic nonspecific cervicitis & 39 & 69.6 & 40 & 71.4 & 0.836 \\
\hline $\begin{array}{l}\text { Chronic nonspecific cervicitis } \\
\text { with excessive mucine material }\end{array}$ & 2 & 3.6 & 5 & 8.9 & 0.438 \\
\hline $\begin{array}{l}\text { Polypoidal chronic nonspecific } \\
\text { cervicitis }\end{array}$ & 6 & 10.7 & 6 & 10.7 & 1.000 \\
\hline $\begin{array}{l}\text { Hyperplastic endometrial } \\
\text { tissue }\end{array}$ & 1 & 1.8 & 0 & 0.0 & 1.000 \\
\hline $\begin{array}{l}\text { Condylomaacuminata(low } \\
\text { grade squamas intraepithelial } \\
\text { lesion) }\end{array}$ & 2 & 3.6 & 3 & 5.4 & 0.647 \\
\hline $\begin{array}{l}\text { Invasive moderately } \\
\text { differentiated squamous cell } \\
\text { carcinoma }\end{array}$ & 1 & 1.8 & 0 & 0.0 & 1.000 \\
\hline $\begin{array}{l}\text { Moderately differentiated } \\
\text { adenocarcinoma }\end{array}$ & 0 & 0.0 & 1 & 1.8 & 1.000 \\
\hline $\begin{array}{l}\text { Non-keratinized squamous cell } \\
\text { carcinoma }\end{array}$ & 0 & 0.0 & 1 & 1.8 & 1.000 \\
\hline $\begin{array}{l}\text { Stratified squamous cervical } \\
\text { inrta epithelial neoplasia grade } \\
\text { II }\end{array}$ & 1 & 1.8 & 0 & 0.0 & 1.000 \\
\hline
\end{tabular}

The sensitivity of cervicoscope was higher than colposcopic which was statistically significant. There was no statistically significant difference between them regarding specificity, + PV, -PV and diagnostic accuracy (Table 6).

Table (6): Diagnostic efficacy of cervicoscope, colposcope.

\begin{tabular}{|c|c|c|c|}
\hline $\begin{array}{ll}\text { Efficacy } & \text { Groups } \\
\end{array}$ & cervicoscope & Colposcope & P-value \\
\hline sensitivity & 75 & 60 & $0.031 *$ \\
\hline Specivicity & 90.38 & 94.12 & 0.288 \\
\hline$+\mathrm{pv}$ & 37.5 & 50 & 0.171 \\
\hline -pv & 97.9 & 96 & 0.7360 \\
\hline Diagnostic accuracy & 89.3 & 91.1 & 0.412 \\
\hline
\end{tabular}




\section{DISCUSSION}

The current study compared the diagnostic accuracy of the office hysteroscopy (cervicoscopy) and stationary colposcopy in diagnosis of cervical lesion in women presented with suspicious cervix. Two tools had been compared in this work namely office hysterescope (cervicoscope) and stationary colposcopy and biopsy as confirmatory method for diagnosis.

The results of our study indicated that more than $60 \%$ of patient complained of vaginal discharge followed by backache in about $60 \%$ and dyspareunia in about $55 \%$ in both groups which was an agreement with Darwish et al. (2013). Moreover, we reported abnormal uterine bleeding more in office cervicoscopic group (46.4\% versus $23.2 \%$ ) which was statistically significant which could be attributed to more use of different methods of contraceptives in this group like COCs, IUD, Deprovera and Implanon (62.6\%, $54.1 \%, 16.2 \%$ and $10.8 \%$ versus $60 \%$, $47.5 \%, 2.5 \%$ and $5 \%$ in both groups respectively). On unaided naked eye examination of the cervix, cervical ectopy was the commonest suspecios lesion which should not be ignored during routine speculum examination. In addition to recurrent cervicitis and postcoital bleeding, cervical ectopy is a precursor of cervical metaplasia which means change of columnar epithelium to squamous epithelium (cellular activity), with a possibility of abnormal cellular pathway to cellular dysplasia at the most dangerous part of the cervix (transformation zone).

In this study, office cervicoscopy succeeded to diagnose abnormal and inflammatory lesions in $14.3 \%$ and $85.7 \%$ respectively with no case of unsatisfactory examination. Contrarily, stationary colposcopy was unsatisfactory in $7.1 \%$. This high sensitivity of office cervicoscopy can be attributed to the ability of the office telescope to freely examine the whole cervix and go inside the endocervical canal, unlike colposcopic lens which is fixed at far distance from the cervix with possibility of magnification again away from the cervix. In a previous study by Valli et al. (2013), cervicoscopic examination revealed $7.8 \%$ of CIN 2-3 in LSIL patients with inadequate or negatine colposcopy.

In this study, we performed cervical biopsy in all cases as histopathology was the cornerstone for diagnosing the nature of cervical lesions. It has been recommended since a long time that at colposcopy two or more biopsies should be taken (Executive Council of the society of Canadian Colposcopists (SOGC / SCC, 2012).

Regarding histopathology of biopsy specimen of the studied women, we documented that chronic cervicitis was the most frequent diagnosis $(91 \%$ in both group) followed by condyloma accumnata low-grade squamous intraepithelial lesion $3.6 \%$ in cervicoscopic group, and $5.4 \%$ in colposcopic group, invasive moderately differentiated squamous cell carcinoma $1.8 \%$ only in cervicoscopic group, stratified squamous cervical intraepithelial neoplasia grade II $1.8 \%$ only in cervicoscopic group, moderately differentiated adenocarcinoma $1.8 \%$ and non-keratinized squamous cell carcinoma $1.8 \%$ only in colposcopic group, In the concordance with our study (Dhakal et al., 2016), documented that $78.70 \%$ had 
chronic cervicitis, $8 \%$ had normal findings, $1.30 \%$ had moderate and $6.70 \%$ had severe squamous intraepithelial lesions. In the present study, the women of cervicoscopic group had higher sensitivity than colposcopic group which was statistically significant. The significant difference between the two methods in sensitivity and the nonsignificant difference between the two methods in specificity, +PV, -PV, diagnostic accuracy means that cervicoscope has the same efficacy as colposcope in evaluating cervical lesions. Moreover, cervicoscope is easier, cheaper, available, safe and widely used in evaluation of endocervical canal and endometrial cavity than colposcope.

In a previous study, we found that cervicoscopy was a simple, cheap and office procedure that can be used as a quick screening tool of HPV infection in women with suspicious cervix. It has the advantage of screening of the rest of the genital tract. In the absence of laporatory HPV testing, performing cervicoscopy in conjunction with cytology screening of high risk cases were encouraged (Darwish et al., 2013).

\section{CONCLUSION}

Office hysteroscopy (cervicoscope) in evaluation of cervical lesions is, simple, widely used, cheaper and can evaluate whole length of cervical canal and endometrial cavity than stationary colposcopy. Cervicoscope can be used as an alternative to colposcopy in the diagnosis of cervical lesions in suspicios cervix.

\section{REFERENCES}

1. American College of Obstetricians and Gynecologists ACOG (2016): Cervical cancer screening and prevention. Practice Bulletin No. 168. Obstet Gynecol., 128: e111-30.

2. Casey PM, Long ME and Marnach ML (2011): Abnormal Cervical Appearance What To Do, When to Worry? Mayo Clin Proc., $86: 147 \mathrm{e} 50$.

3. Centini G, Troia L, Lazzeri L, Petraglia F and Luisi $S$ (2016): Modern operative hysteroscopy. Minerva Ginecologica, 86(2):12632.

\section{Darwish AM, Abdulla Sa,Zahran} Am and Abdel-Fattah NA (2013): Cervicoscopy and microcolposcopy in the evaluation of squamo columnar junction and cervical canal in LSIL patients with inadequate or negative colposcopy. International journal of biomedical science 9(3):148-152.

5. Dhakal R, Makaju R Sharma S, Bhandari S, Shrestha S, and Bastakoti R (2016): Correlation of cervical pap smear with biopsy in the lesion of cervix. Kathmandu University Medical Journal, 14:254257.

6. Ferlay J, Soerjomataram I, Ervik M, Dikshit $R$ and Eser S (2017): GLOBOKAN 2012. Cancer incidence and mortality worldwide. Lyon: International agency for 
Research on cancer. France, 73(8): 648-51.

7. Quaas J, Reich $O$ and Kuppers V (2011): Explanation and use of the RIO 2011 colposcopy nomenclature of the IFCPC (International Federation For Cervical Pathology and Colposcopy) Realiability of unided naked-eye examination as a screening test for cervical lesions in a developing country setup. Journal of Lower Genital Tract Disease, 17(2): 182 -186.

8. Valli E, Fabbri G, Centozone C, Bompianei A, Baiocco F, Larciprete $G$ and Ghinassi A (2013): Cervicoscopy and microcolposcopy in the evaluation of squamo columnar junction and cervical canal in LSIL patients with inadequate or negative colposcopy. International Journal of Biomedical Sciences, 9(3):148-152.

9. Walzer P, Dexeus S, De Palo G, Barrasso $R$, Campion $M$ and Girardi F (2013): International terminology of colposcopy: An update report from international federation for cervical pathology and colposcopy. Obstet Gynecol., 101:175-7.

10. Wentzensen $\mathbf{N}$, Schiffman $M$ and Silver M, (2017): ASCCP Colposcopy Standards: risk-based colposcopy practice. J Low Genit Tract Dis., 21:230-4. 


\section{استخدام منظار عنق الرحم و المنظار الرحمي المكتبي في تقبيم عنق الر حم المشبوه}

محمد ممدوح سيد*، فيصل علي مصطفى*، حسين ع المنعم حسن**، عبدالحليم

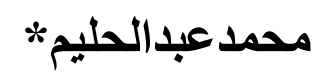

قسم النساء والتوليد*وقسم الباثولوجيا**، كلية طب الأزهر (أسيوط)

E-mail: $\underline{\text { m_mamdouh91@yahoo.com }}$

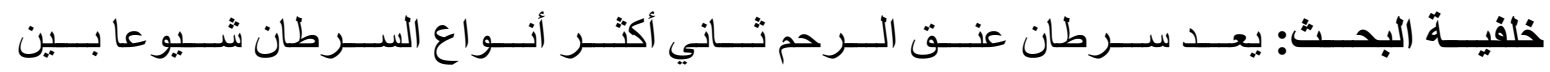

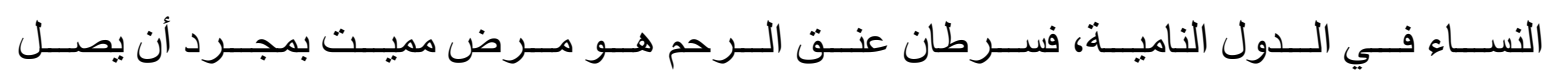

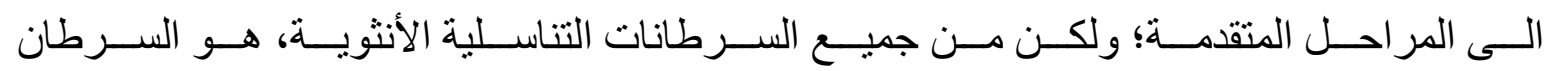

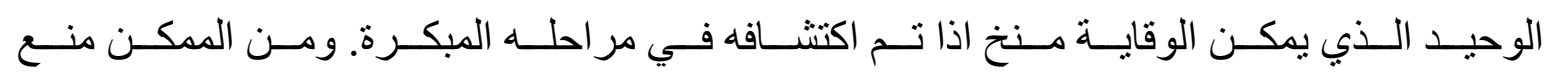

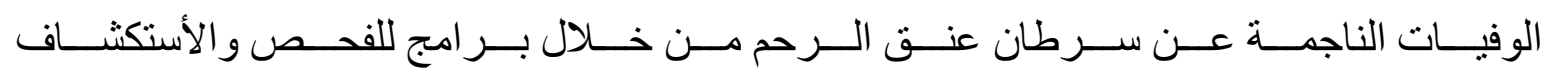

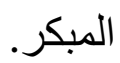

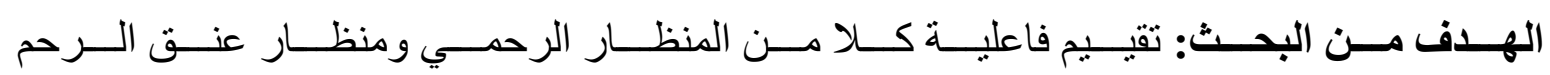
و عينة موجهة بمنظار عنق الرحم وتحليلها باثولوجيا.

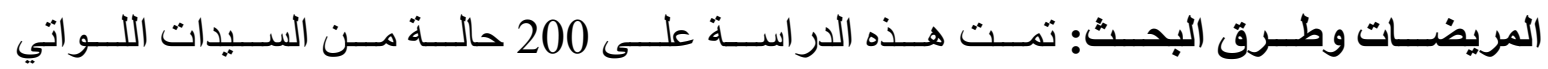

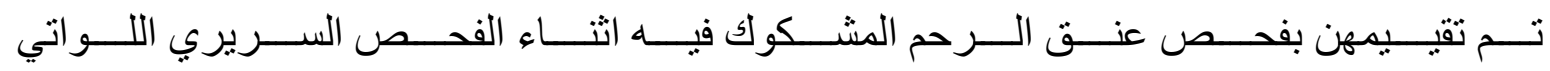

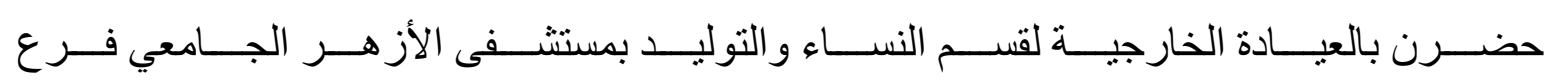
اسيوط. - ان

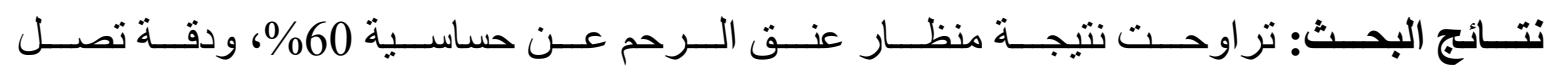

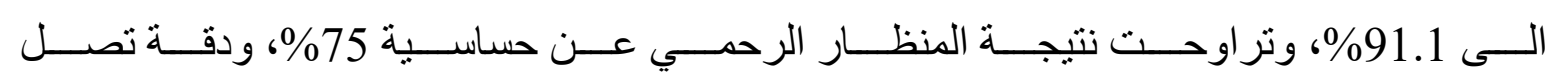

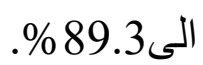

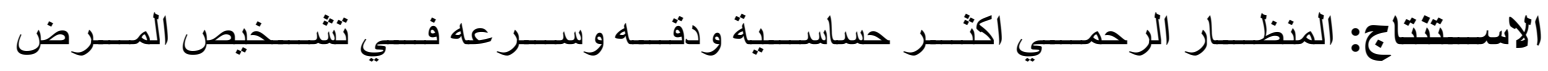
و اكثر فاعلية في تحديد بداية الاور ام عن منظار عنق الرحم. الرحن.

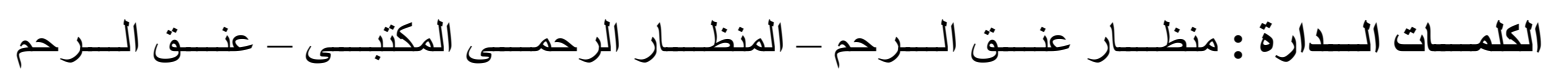

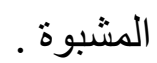

